Огляди літератури, оригінальні дослідження, погляд на проблему, випадок з практики, короткі повідомлення УдК 614.2+616-084+617.7-007.681

DOI 10.11603/1811-2471.2020.v.i2.11328

\title{
КОМПЛАЄНС ХВОРИХ НА ГЛАУКОМУ ЯК МЕДИКО-СОЦІАЛЬНА ПРОБЛЕМА
}

\author{
๑О. Б. Кощинець, О. М. Панько \\ Івано-Франківський начіональний медичний університет
}

РЕЗЮМЕ. Мета - вивчити комплаєнс хворих на глаукому та проаналізувати причини його недостатності.

Матеріал і методи. За спеціальною програмою на базі трьох офтальмологічних відділень стаціонарів трьох центральних районних лікарень Івано-Франківської області обстежили 515 хворих на глаукому у віці понад 55 років. Серед них було 261 жінка і 254 чоловіків (50,7 \% та 49,3%), 249 мешканців міст і 266 сільських жителів (48,3 \% i $51,7 \%)$.

Застосовано соціологічний, бібліосемантичний і медико-статистичний методи.

Результати. Встановлено, що про необхідність постійного прийому ліків знають усі $100 \%$ опитаних хворих на глаукому. Проте більш як третина (36,0%) респондентів не завжди дотримуються рекомендацій офтальмологів і нерегулярно приймають призначені ліки. Однією із основних причин $\epsilon$ те, що 20,4 \% респондентів боїться побічних ефектів ліків від глаукоми і ще 54,7 \% мають сумніви у їх безпеці. Зрозуміло, що така ситуація $\epsilon$ наслідком недостатньої поінформованості пацієнтів щодо терапії, яка їм призначена. 96,9 \% опитаних сказали, що отримують відомості про хворобу від медичних працівників. Серед претензій до медичного обслуговування лише 5,4 \% складали скарги на медперсонал, а дві третини $(67,6$ \%) з числа респондентів, невдоволених медичною допомогою, скаржилися на високу вартість ліків і медичних послуг. 69,0% опитаних заявляли, що іноді чи постійно мають труднощі із оплатою ліків через нестачу коштів.

Висновки. Значна частка хворих на глаукому не дотримуються рекомендацій лікаря та режиму прийому ліків. Причинами низького комплаєнсу $є$ недостатня поінформованість пацієнтів про переваги і ризики лікування, підвищене відчуття тривоги та депресії, самотність, переважно низький рівень матеріального благополуччя і освіти респондентів.

КЛючовІ СлОВА: первинна глаукома; комплаєнс; профілактика сліпоти; лікар загальної практики-сімейний лікар (ЛЗП-СЛ).

Вступ. Первинна глаукома - хронічне повільно прогресуюче захворювання, яке вимагає постійного застосування місцевих гіпотензивних препаратів та диспансерного спостереження. Однак більшість хворих на глаукому використовують призначені їм препарати не регулярно [1]. В іноземній літературі для цього поняття використовують окремий термін - комплаєнс. Комплаєнс - від англійської compliance («згода, відповідність») походить від дієслова to comply - «виконувати» - i буквально означає згоду або бажання хворого виконувати призначення лікаря. I це $\epsilon$ надважливим чинником, який впливає на збереження зорових функцій та якості життя пацієнтів із глаукомою $[2,3]$.

За даними Всесвітньої організації охорони здоров'я (2003), прихильність до тривалої терапії при хронічних захворюваннях у розвинених країнах складає приблизно 50 \%, у країнах, що розвиваються цей показник значно нижчий [4].

Рівень неприхильності збільшується в міру тривалості захворювання. Так, на другий рік хвороби комплаєнс знижується на $20 \%$, а на третій досягає $28,5 \%$. До групи ризику належать пацієнти 50-59 років і старші 80 років (не залежно від гендерної належності). Негативний вплив на дотримання режиму лікування також має супутня патологія (три і більше захворювань) [5].

Тривалість життя населення Землі поступово зростає, відповідно, збільшується й кількість лю- дей похилого віку та асоційованих з ним захворювань. Якщо в 2000 році середній вік населення складав 26,6 року, то в 2050 році він досягне 37,3 року, а до 2100 р. - 45,6 року [6]. Як відомо, поширення глаукоми зростає з віком і зустрічається у 0,1 \% хворих у віці 40-49 років, у 2,8 \% - у 60-69 років і в 14,3 \% - у віці старше 80 років [7]. Тому, за прогнозами, поширеність глаукоми у світі також зросте і до 2040 року буде спостерігатися приблизно у 111,8 млн людей $[3,4,8]$.

Ефективність терапії при глаукомі залежить тільки від призначеного лікування, а й від самого пацієнта. 3 огляду на це важливо виявити можливі причини низького комплаєнсу і розробити ефективні програми із залученням лікарів загальної практики-сімейної медицини для профілактики сліпоти і зменшення показників інвалідності та соціально-економічних збитків.

Мета - вивчити комплаєнс хворих на глаукому та проаналізувати причини його недостатності.

Матеріал і методи дослідження. За спеціальною програмою на базі офтальмологічних відділень стаціонарів трьох центральних районних лікарень Івано-Франківської області обстежили репрезентативну групу 515 осіб, хворих на первинну глаукому. 3 них 347 респондентів з І-ІІ (початковими) стадіями первинної глаукоми та 168 хворих 3 III-IV (пізніми) стадіями захворювання. Крім того, обстежених ділили за статтю (261 жінка і 254 чоло- 
Огляди літератури, оригінальні дослідження, погляд на проблему, випадок з практики, короткі повідомлення віків), віком (до 55, 55-59, 60-64, 65-69, 70-74, 7579, 80 років і старші) та за місцем проживання (249 міських і 266 сільських мешканців).

Розрахували частоту кожного чинника на 100 обстежених і похибку репрезентативності для відносних величин, а оцінку достовірності різниці отриманих даних у групах порівняння проводили за допомогою критерію $\chi^{2}$.

Результати. Аналіз результатів опитування хворих на глаукому показалв, що, попри 100 \% поінформованість про необхідність постійного прийому ліків, тільки $(60,8 \pm 2,2) \%$ респондентів дотримуються його. Решта, а це близько 40 \% хворих на глаукому $((37,1 \pm 2,1) \%)$ визнали, що тільки частково виконують призначення лікаря, і $(2,1 \pm 0,6) \%-$ повністю їх ігнорують. Причому останній показник майже повністю формують хворі, старші 80 років, серед яких кожен десятий $((11,2 \pm 3,3) \%, p<0,001)$ зовсім не приймає ліків.

Крім того, результати соціологічного опитування вказують, що реальні рівні комплаєнсу можуть бути ще нижчими. Адже тільки $(36,1 \pm 2,1) \%$ респондентів зазначили, що ніколи не пропуска-

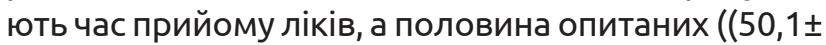
$2,2) \%$ епізодично, і ще $(13,8 \pm 1,5)$ \% систематично не дотримуються належної періодичності прийому ліків. Причому вдвічі частіше повністю порушують режим закапування препаратів сільські жителі $((19,5 \pm 2,4)$ \% проти $(7,7 \pm 1,7)$ \% міських мешканців, $\mathrm{p}<0,001)$ і хворі з пізніми стадіями глаукоми $((21,4 \pm$ $3,2) \%$ проти $(10,1 \pm 1,6)$ \% серед респондентів з I-

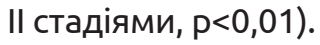

Очевидно, що причини такого низького комплаєнсу багатогранні. Зокрема, встановлено, що, незалежно від статі, місця проживання та стадії захворювання, тільки третина опитаних $((31,8 \pm 2,1) \%$ і їх частка прогресивно зменшувалась із віком, p<0,001) відзначили, що не мали фінансових перешкод для постійного лікування. Натомість більшість респондентів скаржились на те, що час від часу потрапляють у ситуації, коли не вистачає ко-

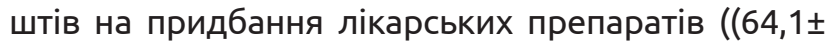
$2,1) \%)$, а $(4,1 \pm 0,9) \%$ (головним чином за рахунок $(13,5 \pm 3,6)$ \% хворих старших 80 років) відчували їх постійну нестачу. Встановлені особливості зіставні з соціально-економічними характеристиками розглянутого контингенту населення.

Абсолютна більшість респондентів - особи похилого віку (понад 60 років), тобто пенсіонери та інваліди (88,5 \%). Відповідно, 85,6 \% опитаних мали середній дохід на одного члена сім'ї, менший від прожиткового мінімуму. Майже у кожного п'ятого хворого на глаукому $(17,7 \%)$ він нижчий за встановлену державою межу бідності. Вищу освіту мали тільки 14,6 \% опитаних, натомість у третини (33,3 \%) з них - освіта нижче середньої.

3 огляду на встановлені особливості соціально-економічного статусу хворих на глаукому (більшість з них - літні люди з низькими доходами та рівнем освіти, пенсіонери або інваліди) важливу роль у їх соціальній адаптації мали 6 відігравати сім'я та близькі. Спільне проживання 3 родиною підвищує комплаєнс, однак тут присутній елемент залежності від сторонньої допомоги (рідні не завжди мають можливість інстилювати препарат вчасно).

Порівняльний аналіз сімейного стану засвідчив, що хоча більшість респондентів $((64,5 \pm 2,1) \%)$ перебували у шлюбі, третина хворих $((35,6 \pm 2,1) \%)$ з первинною глаукомою - самотні особи, які не мають звідки очікувати допомоги. Сімейний стан респондентів цілком закономірно змінювався 3 віком ( $<<0,001)$, в основному за рахунок зростання частки вдівців (з нуля серед осіб молодших за 55 років до $(77,5 \pm 4,4) \%$ у віці понад 80 років). Особливо тривожить висока частка самотніх серед хворих з пізніми стадіями захворювання $(p<0,01)$, які, як уже вказувалось, зазвичай мають виражені порушення зору і як ніхто потребують сторонньої допомоги та підтримки. Результати дослідження показали, що практично половина 3 них $((45,3 \pm 3,8) \%)$ - самотні.

Досить поширеними серед респондентів виявились скарги на наявність дистресів у їх житті. Стабільне відчуття тривоги та депресії, незалежно від віку, статі, місця проживання $(p>0,05)$ виявлено практично у кожного шостого хворого на глаукому $((16,1 \pm 1,6) \%)$, а у абсолютної більшості $((78,6 \pm 1,8) \%)$ опитаних воно виникало час від часу.

У хворих з пізніми стадіями глаукоми скарг на постійні часті стреси зареєстровано удвічі більше - $(24,4 \pm 3,3) \%$, порівняно із $(12,1 \pm 1,8) \%$ хворих з початковим перебігом ( $<<0,001)$. Очевидно, визнання невиліковності захворювання і страх можливої втрати зору викликає негативні емоції, збільшує тривогу та депресію.

Окрім абсолютно закономірних соціальноекономічних причин низького комплаєнсу у дослідженні показаний можливий вплив медико-інформаційних чинників. На користь висловленої гіпотези свідчить низка встановлених у дослідженні фактів. Зокрема, виявлено, що тільки кожен четвертий респондент $((24,9 \pm 1,9) \%)$, незалежно від віку, статі і тяжкості глаукомного ураження ( $>0,05)$, заявив, що не боїться побічної дії ліків, які приймає. Половина опитаних $((54,7 \pm 2,2) \%)$ визнали, що мають часткові побоювання, а кожен п'ятий $((20,4 \pm 1,8) \%)$ постійно сумнівається в безпечності призначених препаратів. Причому, міські респонденти загалом мали вищий рівень освіти і значно частіше висловлювали стабільну тривогу щодо по- 
Огляди літератури, оригінальні дослідження, погляд на проблему, випадок з практики, короткі повідомлення бічних ефектів від вживання ліків $((31,0 \pm 2,9) \%$ проти $(10,5 \pm 1,9) \%$ сільських мешканців, $p<0,001)$. Разом з тим, вони достовірно рідше, ніж сільські мешканці, займались самолікуванням $((12,4 \pm 2,1) \%$ проти $(18,9 \pm 2,4) \%$ відповідно, разом - $(15,8 \pm 1,6) \%$, $\mathrm{p}<0,05)$.

Тільки четверта частина опитаних $((25,4 \pm 1,9) \%)$ були переконані у ефективності ліків, які їм приписані. Більшість же респондентів $((69,7 \pm 2,0) \%)$ мали часткові сумніви щодо позитивних наслідків призначеної терапії, а $(4,9 \pm 0,9)$ \% взагалі в неї не вірили. Відсоток повністю зневірених зростав із віком (до $(15,7 \pm 3,9) \%$ у 80-річних та старших, $\mathrm{p}<0,01)$ та тяжкістю захворювання $((10,7 \pm 2,4) \%$ проти $(2,0 \pm$ $0,8)$ \% з початковими стадіями, $p<0,001)$. Оскільки медикаментозне лікування при глаукомі спрямоване на стабілізацію процесу і запобігання подальшому прогресуванню, навіть регулярне застосування очних капель, як правило, не приводить до суб'єктивного поліпшення зорових функцій. На наш погляд, якби на цьому постійно наголошувалось при співбесіді із лікарем, результати опитування були 6 інакші. Інформуючи пацієнтів, лікарі повинні враховувати їх вік, рівень освіти, когнітивні здібності тощо. Зрозуміло, що лікар-офтальмолог, який бачить свого пацієнта, як було показано, у кращому випадку один раз на рік, не має достатніх умов і можливостей, щоб пояснити (часто повторно, зокрема особам літнього і старечого віку) особливості перебігу захворювання, мету лікування, ознаки стабільності чи прогресування глаукоми та проконтролювати, чи дотримується пацієнт рекомендацій. У цьому напрямку неоціненний внесок мав би робити ЛзП-СЛ, основним призначенням якого $€$ постійний «патронаж» приписаних до нього мешканців.

Результати опитування хворих на глаукому показали, що майже $40 \%((36,5 \pm 2,1) \%)$ з них не мають повної довіри до свого сімейного лікаря, кожен десятий з них $((10,3 \pm 1,3) \%)$ взагалі його не знає, причому серед хворих у віці понад 80 років таких $(20,2 \pm 4,3) \%, p<0,05$.

Сільські мешканці загалом у 1,5 раза більш доброзичливо оцінювали свою довіру до ЛзП-СЛ (70,3 \% проти 56,3 \% міських респондентів, p $<0,001)$. Хоча дивує, що майже однаковими тут виявились частки тих, хто не знає і не довіряє своєму ЛЗП-СЛ.

Жінки-респонденти, які значно уважніше ставляться до власного здоров'я, цілком логічно виявились більш поінформованими (6,5 \% проти 14,2 \% чоловіків) та доброзичливо налаштованими (68,8 \% проти $58,1 \%)$ до свого Л3П-СЛ $(p<0,01)$.

3 огляду на сказане зрозуміло, чому тільки $37,5 \pm 2,1$ із 100 опитаних хворих на глаукому, незалежно від статі та стадії захворювання, вислови-

ли бажання надалі лікуватись та спостерігатись у ЛЗП-СЛ, порівняно з $(70,2 \pm 2,0) \%$ тих, хто надає перевагу лікарям-спеціалістам. Слід зазначити, що частіше хотіли 6 перебувати під патронатом сімейного лікаря хворі старечого віку $((52,8 \pm 5,3) \%$ опитаних у віці понад 80 років, $p<0,05)$ та, як не дивно, мешканці міст $((51,2 \pm 3,2) \%$ проти $(24,8 \pm 2,6) \%$ мешканців сіл, $\mathrm{p}<0,001)$. Можливо, на такі відповіді вплинула краща поінформованість міських жителів щодо переваг сімейної медицини і їх перспектив у майбутньому. Сільські мешканці, які часто мають гірший доступ до спеціалізованої допомоги, частіше висловлювали побажання лікуватись та спостерігатись з приводу глаукоми саме у лікарів-офтальмологів (80 проти 50).

Вивчення джерел отримання медичної інформації хворими на глаукому показало в цілому задовільні показники. Абсолютна більшість з них $(95,7 \pm 0,9$ на 100 опитаних), незалежно від статі i стадії захворювання, називали в якості основного джерела медичних працівників. Кожен десятий респондент $((10,9 \pm 1,4) \%)$ вказав, що поповнює свої знання на медичні теми із засобів масової інформації і зовсім незначні частки опитаних схильні орієнтуватися на поради родичів, знайомих $((5,8 \pm 1,0) \%)$ чи інших джерел $((2,3 \pm 0,7) \%) .3$ віком мінялись преференції тільки стосовно засобів масової інформації, роль яких суттєво знижувалась із настанням старечого віку (до 3,4-3,6 \% після 75 років, $p<0,05)$. У 2,5 раза рідше опирались на це джерело й мешканці сіл - $(6,0 \pm 1,5)$ \% проти $(16,1 \pm 2,3) \%(p<0,01)$.

Встановлені медико-організаційні недоліки, очевидно, відобразилися на тому, що майже $40 \%$ $((35,5 \pm 2,1) \%)$ опитаних мали претензії до медичного обслуговування, частота яких зростала із віком опитаних (до $(56,2 \pm 4,6) \%$ у понад 80 -річному віці, р<0,001) та більш акцентовано проявлялась серед міських жителів $((41,0 \pm 3,1) \%$ проти $(20,5 \pm$ $2,8) \%$ серед мешканців сіл, $p<0,05)$.

Найчастіше хворі скаржилися на неможливість оплатити ліки, віддаленість медичного закладу та високу вартість медичних послуг.

Слід зазначити, що нарікання на фінансову недоступність медикаментів і віддаленість від місця надання медичної допомоги закономірно зростали з віком опитаних (до 36,0 \% та 18,0 \% відповідно, $\mathrm{p}<0,05)$ та особливо акцентовано - із прогресуванням хвороби (до $60,9 \%$ та $47,8 \%$ у хворих із III-IV стадіями проти 12,7 \% та $2,5 \%$ у хворих із III стадіями, $\mathrm{p}<0,05)$.

Висновки. Значна частка хворих на глаукому не дотримуються соціально-побутових порад лікаря-офтальмолога і лікаря загальної практики сімейного лікаря та рекомендацій щодо кратності, тривалості застосування препаратів, заперечу- 
Огляди літератури, оригінальні дослідження, погляд на ють диспансеризацію. Важливим рішенням для збереження функцій ока є вчасна згода на оперативне (лазерне або хірургічне) лікування. Причинами низького комплаєнсу $є$ недостатня поінформованість пацієнтів про ризики, пов'язані з повною або частковою відмовою від лікування, підвищене відчуття тривоги та депресії, самотність, низький рівень матеріального благополуч- облему, випадок з практики, короткі повідомлення чя респондентів, абсолютна більшість яких $є$ пенсіонерами та інвалідами.

Перспективи подальших досліджень. Отримані нами результати дослідження будуть сприяти розробці ефективних програм із залученням лікарів загальної практики - сімейної медицини для підвищення прихильності до лікування хворих на глаукому.

\section{ЛІТЕРАТУРА}

1. Диагностика и лечение глаукомы. Дополнение к лекциям / Рыков С. А. и др. -2-е изд. - К. : АСАВА, 2014. $72 \mathrm{c.}$

2. Егоров Е. А. Глаукома. Национальное руководство / Е. А. Егоров. - М. : ГЭОТАР-Медиа, 2013. - 824 с.

3. Казанова С. Ю. Анализ приверженности лечению пациентов с хроническими заболеваниями. / С. Ю. Казанова // Национальный журнал глаукома. - 2018. № 17 (3). - C. 97-110. DOI: 10.25700/NJG.2018.03.11.

4. World Health Organization. Adherence to long-term therapies: evidence for action. World Health Organization. - Geneva, 2003.

5. Frech S. Pharmacoepidemiological assessment of adherence and influencing co-factors among primary openangle glaucoma patients - An observational cohort study / S. Frech // Plos ONE. - 2018. - No. 13 (1). - e0191185. DOI: 10.1371/journal.pone.0191185.

\section{REFERENCES}

1. Rykov, S.A. (2014). Diagnostika i lechenye glaukomy. Dopolnenye $k$ lektsiyam [Diagnosis and treatment of glaucoma. Lecture supplement]. Kyiv: ASAVA [in Russian].

2. Egorov E.A. (2013). Glaukoma. Natsyonalnoe rukovodstvo [Glaucoma. National leadership]. Moscow: "GEOTAR-Media" [in Rssian].

3. Kazanova, S.Yu. (2018). Analiz pry verzhennosti lecheniyu patsiyentov s khronicheskymi zabolevaniyami [Treatment adherence analysis for patients with chronic diseases]. Natsionalnyy zhurnal glaukoma - National Journal Glaucoma, 17 (3), 97-110. Retrieved from: https://doi. org/10.25700/NJG.2018.03.11 [in Russian].

4. (2003). World Health Organization. Adherence to long-term therapies: evidence for action. Geneva.

5. Frech, S. (2018). Pharmacoepidemiological assessment of adherence and influencing co-factors among primary open-angle glaucoma patients - An observational cohort study. Plos ONE, 13 (1), e0191185. DOI: 10.1371/
6. Lutz W. The coming acceleration of global population ageing / W. Lutz, W. Sanderson, S. Scherbov // Nature. - 2008. - No. 451 (7179). - P. 716-719. DOI: $10.1038 /$ nature06516.

7. Линденбратен А. Л. Эффективность скрининга глаукомы в рамках диспансеризации лиц с хроническими неинфекционными заболеваниями / А. Л. Линденбратен, И. Б. Алексеев, М. А. Аливердиева // Проблеми социальной гигиены, здравоохранения и истории медицини. - 2017. - No. 25 (4).

8. Global prevalence of glaucoma and projections of glaucoma burden through 2040: a systematic review and meta-analysis / Y. C. Tham, X. Li, T. Y. Wong [et al.] // Ophthalmology. - 2014. - No. 121 (11). - P. 2081-2090. DOI:10.1016/j.ophtha.2014.05.013.

journal.pone.0191185.

6. Lutz, W., Sanderson, W., \& Scherbov, S. (2008). The coming acceleration of global population ageing. Nature, 451 (7179), 716-719. DOI: 10.1038/ nature06516.

7. Lyndenbraten, A.L., Alekseev, I.B., \& Aliverdyeva, M.Ya. (2017). Effektivnost skryninga glaukomy v ramkakh dyspanserizatsii lits s khronicheskymy neinfektsyonnymi zabolevaniyami [The effectiveness of glaucoma screening as part of the clinical examination of people with chronic noncommunicable diseases]. Problemy sotsyalnoy gigiyeny, zdravookhraneniya $i$ istorii meditsyny - Problems of Social Hygiene, Healthcare and the History of Medicine, 25 (4) [in Russian].

8. Tham, Y.C., Li, X., Wong, T.Y., Quigley, H., Aung, T., \& Cheng, C.Y. (2014). Global prevalence of glaucoma and projections of glaucoma burden through 2040: a systematic review and meta-analysis. Ophthalmology, 121 (11), 2081-2090. DOI:10.1016/j.ophtha.2014.05.013. 


\author{
Ивано-Франковский национальный медицинский университет
}

РЕзЮМЕ. Цель работы - изучить комплаенс больных глаукомой и проанализировать причины его недостаточности.

Материал и методы. Исследование проводилось на базе офтальмологических отделений стационаров трех центральных районных больниц Ивано-Франковской области. Опрошена репрезентативная группа из 515 больных глаукомой в возрасте старше 55 лет. Среди них была 261 женщина и 254 мужчин (50,7 \% и 49,3 \%), 249 городских и 266 сельских жителей (48,3 \% и 51,7 \%). Применены социологический, библиосемантичний и медико-статистический методы.

Результаты. Установлено, что о необходимости постоянного приема лекарств знают все $100 \%$ опрошенных больных глаукомой. Однако более трети (36,0 \%) респондентов не всегда следуют рекомендациям офтальмологов и нерегулярно принимают назначенные лекарства. Одной из основных причин является то, что 20,4 \% респондентов боятся побочных эффектов лекарств от глаукомы и еще 54,7 \% сомневаются в их безопасности. Понятно, что такая ситуация является следствием недостаточной осведомленности пациентов относительно терапии, которую им назаначают. 96,9 \% опрошенных сказали, что получают сведения о болезни от медицинских работников. Среди претензий к медицинскому обслуживанию, жалобы на медперсонал были лишь в 5,4 \% случаев, а две трети (67,6 \%) из числа респондентов, недовольных медицинской помощью, жаловались на высокую стоимость лекарств и медицинских услуг. 69,0 \% опрошенных заявляли, что иногда или постоянно испытывают трудности с оплатой лекарств из-за нехватки средств.

Выводы. Значительная часть больных глаукомой не соблюдают рекомендации врача и режим приема лекарств. Причинами низкого комплаенса является недостаточная осведомленность пациентов о преимуществах и рисках лечения, повышенное чувство тревоги и депрессии, одиночество, преимущественно низкий уровень материального благополучия и образования респондентов.

КЛЮчЕВЫЕ СЛОВА: первичная глаукома; комплаенс; профилактика слепоты; врач общей практики.

\title{
COMPLIANCE OF GLAUCOMA PATIENTS AS A MEDICAL AND SOCIAL PROBLEM
}

@O. B. Koshchynets, O. M. Panko

\section{Ivano-Frankivsk National Medical University}

SUMMARY. The aim of the work - to study the compliance of patients with glaucoma and analyze the causes of its insufficiency.

Material and Methods. The study was conducted on the basis of the ophthalmological departments of hospitals of three central district hospitals of the Ivano-Frankivsk region. A representative group of 515 glaucoma patients over 55 years old was interviewed. Among them were 261 women and 254 men (50.7\% and $49.3 \%$ ), 249 urban and 266 rural residents (48.3\% and $51.7 \%$ ). Sociological, bibliosemantic and medico-statistical methods were applied.

Results. It was established that the need for constant medication is known to all $100 \%$ of respondents with glaucoma. However, more than a third (36.0 \%) of respondents do not always follow the recommendations of ophthalmologists and do not regularly take prescribed medications. One of the main reasons is that $20.4 \%$ of respondents fear the side effects of glaucoma medications and another $54.7 \%$ doubt their safety. It is clear that this situation is the result of a lack of patient awareness of the therapy that they are prescribed. $96.9 \%$ of respondents said they receive information about the disease from health workers. Among claims to medical care, complaints about medical staff were only in $5.4 \%$ of cases, and two thirds (67.6\%) of the number of respondents dissatisfied with medical care complained about the high cost of drugs and medical services. $69.0 \%$ of respondents said that they sometimes or constantly have difficulty paying for medicines due to lack of funds.

Conclusions. A significant number of patients with glaucoma do not comply with the recommendations of the doctor and the regimen of medication. The reasons for the low compliance are the lack of patient awareness of the benefits and risks of treatment, an increased feeling of anxiety and depression, loneliness, mainly a low level of material well-being and the education of respondents.

KEY WORDS: primary glaucoma; compliance; preventive blindness; primary care physician. 